\title{
PERKEMBANGAN MUSIK KESENIAN GATHOLOCO CIPTO BUDOYO KABUPATEN TEMANGGUNG
}

\author{
Eko Kristiyanto \\ Alumni Jurusan Karawitan Fakultas Seni Pertunjukan \\ Institut Seni Indonesia (ISI) Surakarta \\ Email: kristiyantoeko113@gmail.com \\ Muhammad Nur Salim \\ Dosen Jurusan Karawitan Fakultas Seni Pertunjukan \\ Institut Seni Indonesia (ISI) Surakarta \\ Email: denmassalim88@gmail.com
}

\begin{abstract}
Abstrak
Penelitian ini bertujuan untuk mengungkap mengenai perkembangan musikal kesenian Gatholoco Cipto Budoyo Desa Kembangsari. Permasalahan utama yang dibahas adalah tentang periodisasi perkembangan musikal serta faktor-faktor yang mempengaruhinya. Untuk menjawab permasalahan tersebut, peneliti menggunakan konsep musik khususnya tentang garap dan konsep tentang perkembangan yang merujuk pada konsep periodisasi dan faktorfaktor penyebab perkembangan. Pendekatan yang digunakan adalah antropologi sosial dan musikologi dengan menggunakan metode deskripstif analisis. Hasil dari peneilitian ini mengungkap bahwa perkembangan musikal kesenian Gatholoco kelompok seni Cipto Budoyo Desa Kembangsari terjadi secara periodik, yakni melalui beberapa tahapan masa atau waktu. Periode pertama terjadi pada tahun 1963-1980, kemudian periode kedua terjadi pada tahun 1981-2000 dan periode ketiga terjadi pada tahun 2001-2018. Perkembangan musikal yang terjadi pada masing-masing periode dapat dilihat dari unsur-unsur garap diantaranya: materi garap, penggarap, sarana garap, prabot atau piranti garap, penentu garap, serta pertimbangan garap. Perkembangan musikal kesenian Gatholoco Cipto Budoyo terjadi karena adanya beberapa faktor pendukung. Faktor-faktor pendukung tersebut berasal dari dalam (internal) dan dari luar (eksternal).
\end{abstract}

Kata kunci: Gatholoco, musikal, periodisasi, perkembangan, faktor-faktor.

\begin{abstract}
This research aims to reveal the musical development of the Gatholoco Cipto Budoyo Kembangsari Village. The main problem discussed is about the periodization of musical development and the factors that influencing it. To answer this problem, researchers use the concept of music specifically about work and the concept of development that refers to the concept of periodization and the factors that cause development. The approach used is social anthropology and musicology by using descriptive analysis methods. The results of this study revealed that the musical development of the art group Gatholoco Cipto Budoyo, Kembangsari Village that occurred periodically through several stages of time. The first period occurred in 1963-1980, then the second period occurred in 1981-2000 and the third period occurred in 2001-2018. Musical developments that occur in each period can be seen from the elements of cultivation including: works on material (garap), instrument players, facilities of the works (garap), instruments and determinants of the works (garap), and the consideration of the works (garap). The musical art development of Gatholoco Cipto Budoyo was due to several supporting factors. These supporting factors come from within (internal) and from outside (external).
\end{abstract}

Keywords: Gatholoco, musical, periodization, development, factors. 


\section{Pengantar}

Berbagai macam bentuk kesenian rakyat hingga sekarang masih hidup dan berkembang di Kabupaten Temanggung, salah satunya yakni kesenian Gatholoco. Gatholoco merupakan salah satu seni pertunjukan rakyat yang memadukan antara seni musik, dan seni tari, serta dilengkapi dengan selingan (lelucon) dalam pertunjukannya. Gatholoco berasal dari dua kata, yaitu: gatho dan loco. Kata gatho berasal dari gathuk yang berarti cocok atau sesuai, sedangkang loco berarti lucu. Pengertian istilah Gatholoco apabila digabungkan memiliki arti mencocok-cocokkan atau memadukan sesuatu hal yang bersifat lucu. Istilah Gatholoco, dalam Ensiklopedi Tari Indonesia, memiliki pengertian sebagai berikut.

Mereka melihat prajurit Keraton, orang cebol, orang bule dan sebagainya. Atas dasar apa yang mereka saksikan itu semua, timbul inspirasi untuk menciptakan tarian yang merupakan peniruan dan digarap menurut daerahnya. Para pemain memakai topeng yang dibuat dari pelepah bambu (climpring: Jawa). Kemudian dikembangkan menjadi topeng kayu yang jauh lebih baik buatannya. Gerak tari bersifat lucu dan mengikuti iringannya. Pakaian penari bebas dan mengutamakan sifat kelucuan yang bisa menarik penonton. Sebutan Gatholoco menurut para pelakunya berarti sesuai dan lucu (gatho : gathuk: sesuai) ; (loco : lucu), sebagai tontonan hiburan rakyat (Wibisono dkk, 1985 : 23).

Kesenian Gatholoco Cipto Budoyo terdiri dari dua unsur pertunjukan, yaitu pertunjukan musik dan tari. Sajian pertunjukan kesenian Gatholoco Cipto Budoyo tidak berdiri sendiri, melainkan saling berkaitan erat antara musik dengan tarinya. Sajian musik kesenian Gatholoco Cipto Budoyo terdapat dua bentuk, yaitu instrumen dan vokal lagu. Bentuk lagu dalam kesenian Gatholoco Cipto Budoyo yakni berisi geguritan bebas dan parikan. Isi teks dalam lagunya mengandung nilai-nilai hidup bermasyarakat seperti kegiatan masyarakat sehari-hari, adat kebiasaan, dan pendidikan. (Tri Puji Waluyo, wawancara 30 september 2017)

Keberadaan kesenian Gatholoco Cipto Budoyo telah mengalami perkembangan seiring dengan situasi dan kondisi masyarakat pendukung. Salah satu perkembangan yang terjadi dalam sajian pertunjukan kesenian Gatholoco Cipto Budoyo adalah dari segi musikalitasnya. Perkembangan dari segi musikalitas kesenian Gatholoco Cipto Budoyo meliputi, garap alur sajian pertunjukan, penambahan instrumen, vokabuler lagu dan senggakan. Hal tersebut menarik untuk diteliti untuk mengungkap dua permasalahan utama yakni tentang periodisasi perkembangan musikal dan faktor-faktor yang mempengaruhi perkembangan musikal kesenian Gatholoco Cipto Budoyo Desa Kembangsari Kecamatan Kandangan Kabupaten Temanggung

Guna mengetahui proses perkembangan musikal kesenian Gatholoco Cipto Budoyo, diperlukan pembagian waktu atau periode di dalam proses perkembangan tersebut. Hal tersebut seperti yang diungkapkan Kartodirdjo (1992: 78-79) sebagai berikut.

Oleh karena dimensi waktu dalam studi sejarah paling esensial, maka sangatlah wajar apabila setiap penulisan sejarah mencakup tidak hanya penetapan waktu tetapi lebih-lebih memberi bentuk kepada waktu, sehingga waktu juga menunjukkan struktur. Kronologi sering disajikan sebagai deretan peristiwa teratur menurut urutan mulai yang terlebih dahulu terjadi sampai yang terahir.

Pembagian periode atau dimensi waktu dalam perkembangan musikal kesenian Gatholoco Cipto Budoyo sangat penting. Periode merupakan dasar yang digunakan untuk mengetahui perkembangan yang terjadi. Periodisasi didasarkan pada bentuk dan struktur dari sajian musikal kesenian Gatholoco Cipto Budoyo yang berbeda antara periode pertama, ke dua, dan ke tiga. 
Perbedaan bentuk dan struktur sajian musikal kesenian Gatholoco Cipto Budoyo terletak pada alur sajian, jumlah instrumen yang digunakan, dan penambahan vokabuler lagu, serta senggakan dalam pertunjukan kesenian Gatholoco Cipto Budoyo. Sajian musikal kesenian Gatholoco Cipto Budoyo dalam pertunjukannya terdapat ke enam unsur garap sebagaimana diungkapkan oleh Supanggah. Konsep garap Supanggah tersebut dapat digunakan untuk melihat perkembangan musikal pada kesenian Gatholoco Cipto Budoyo. Supanggah (2007: 34) menjelaskan pengertian garap sebagai berikut.

Garap merupakan rangkaian kerja kreatif dari (seseorang atau sekelompok) pengrawit yang dalam menyajikan sebuah gending atau komposisi karawitan untuk menghasilkan wujud (bunyi), dengan kualitas atau hasil tertentu sesuai dengan maksud, keperluan atau tujuan dari satu kekaryaan atau penyajian karawitan dilakukan. Garap melibatkan beberapa unsur atau pihak yang masing-masing saling terkait dan membantu. Dalam karawitan Jawa, beberapa unsur garap tersebut dapat disebut sebagai berikut; (1) materi garap, (2) penggarap, (3) sarana garap, (4) prabot atau piranti garap, (5) penentu garap, pertimbangan garap

Proses perkembangan tersebut tidak serta merta hadir begitu saja, namun dipengaruhi oleh beberapa faktor yakni faktor internal dan faktor eksternal. Hal tersebut sesuai dengan pendapat Boskoff (1964: 143147) dalam Nawan Perwita Putra (2012 : 14) sebagai berikut.

"Perubahan itu sendiri disebabkan oleh dua faktor, yakni faktor internal dan eksternal. Faktor eksternal adalah sebuah perubahan terjadi karena adanya kontak antar budaya yang berbeda, sedangkan faktor internal adalah terjadinya suatu perubahan disebabkan adanya perubahan yang terdapat dalam masyarakat itu sendiri."
Faktor eksternal disebabkan oleh kondisi sosial masyarakat yang terpengaruh modernisasi, sehingga membawa dampak terhadap perkembangan musikal kesenian Gatholoco Cipto Budoyo untuk disesuaikan dengan selera masyarakat pendukung kesenian Gatholoco Cipto Budoyo. Faktor internal yang dimaksud disebabkan oleh faktor kesenimanan atau pelaku seni itu sendiri.

\section{Periodisasi Perkembangan Musik Kesenian Gatholoco Cipto Budoyo (1963-2018)}

Perkembangan musikal kesenian Gatholoco Cipto Budoyo ini dibagi menjadi tiga tahapan periode. Periode pertama terjadi pada tahun 1963 sampai tahun 1980, merupakan awal mula keberadaan sajian musikal kesenian Gatholoco Cipto Budoyo. Periode ke dua terjadi pada tahun 1981 sampai tahun 2000, merupakan masa awal mulainya perkembangan sajian musikal kesenian Gatholoco Cipto Budoyo terlihat lebih menonjol dibanding dengan periode pertama. Periode ke tiga terjadi pada tahun 2001 sampai 2018, merupakan masa perkembangan musikal kesenian Gatholoco Cipto Budoyo terlihat lebih kompleks dibandingkan dengan periode-periode sebelumnya. Pembagian periode atau dimensi waktu dengan melihat bentuk musikalitas kesenian tersebut menjadi dasar yang digunakan untuk mengetahui perkembangan musikalitas dalam periode tertentu.

Proses perkembangan yang terjadi pada musikalitas kesenian Gatholoco Cipto Budoyo, dilakukan melalui beberapa tahapan. Tahap pertama, dilakukan pelacakan dan penafsiran musikalitas kesenian Gatholoco Cipto Budoyo pada masa awal keberadannya. Tahap ke dua, dilakukan pelacakan dan membandingkan dari setiap masa atau waktu yang ditemukan indikasi adanya perkembangan. Tahap ke tiga, berdasarkan masa yang telah ditentukan, ditemukan indikasi adanya perkembangan dan dilakukan pelacakan atas faktor-faktor dalam lingkungan sekitar kelompok kesenian Gatholoco Cipto Budoyo berada, serta proses adaptasi pelaku seni kesenian Gatholoco Cipto 
Budoyo terhadap lingkungan penyebab perkembangan.

Pembagian ketiga periode tersebut didasarkan pada bentuk dan struktur musikal kesenian Gatholoco Cipto Budoyo yang berbeda antara periode pertama, ke dua, dan ke tiga. Perbedaan bentuk dan struktur musikal kesenian Gatholoco Cipto Budoyo tersebut yakni terletak pada alur sajian pertunjukannya. Jumlah instrumen yang digunakan dan penambahan vokabuler lagu, serta vokal senggakan, juga berpengaruh dalam perkembangan musikal Gatholoco Cipto Budoyo. Periode pertama merupakan awal mula terbentuknya musikalitas kesenian Gatholoco Cipto Budoyo. Periode ke dua merupakan masa awal perkembangan musikal kesenian Gatholoco Cipto Budoyo. Periode ke tiga merupakan masa perkembangan musikal kesenian Gatholoco Cipto Budoyo yang terlihat lebih menonjol dan kompleks dibandingkan dengan periode-periode sebelumnya.

Alur sajian pertunjukan kesenian Gatholoco Cipto Budoyo terbagi menjadi tiga bagian, yakni bagian awal, tengah, dan akhir. Bagian awal pertunjukan kesenian Gatholoco Cipto Budoyo ditandai dengan penyajian lagu yang berjudul Atur Sugeng. Lagu tersebut disajikan pada awal pertunjukan yang berfungsi sebagai ucapan selamat datang kepada para penonton. Bagian ini para penari mulai memasuki arena atau tempat pementasan untuk mempersiapkan diri pada posisi masing-masing. Bagian tengah pertunjukan kesenian Gatholoco Cipto Budoyo berisi tentang nasihat-nasihat yang tersirat dalam cakepan teks vokabuler lagu Gatholoco Cipto Budoyo. Nasihat tersebut berupa nasihat agar senantiasa menjaga persatuan dan kesatuan, bersikap gotong royong, dan selalu berusaha untuk belajar. Bagian akhir pertunjukan kesenian Gatholoco Cipto Budoyo ditandai dengan sajian lagu yang berjudul Kembang Resah. Lagu ini disebut juga "lagu pamitan" oleh para pelaku kesenian Gatholoco Cipto Budoyo, sebab cakepan teks lagu tersebut berisi permintaan maaf oleh para pemain Gatholoco atas kekurangan dan kesalahan selama pementasan berlangsung.
Pembahasan pada bab ini difokuskan pada segi musikal dalam sajian pertunjukan kesenian Gatholoco Cipto Budoyo. Peran musik menjadi sangat penting, dan dapat menentukan sajian bentuk pertunjukan yang disertainya. Pernyataan tersebut dipertegas oleh Soedarsono (1976: 24) dalam bukunya yang berjudul Pengantar Pengetahuan Tari, bahwa “...sejak zaman prasejarah sampai sekarang dapat dikatakan dimana ada tari di sana ada musik. Musik dalam tari bukan hanya sekedar iringan, tetapi musik adalah partner tari yang tidak boleh ditinggalkan".

Musik dalam sajian pertunjukan kesenian Gatholoco Cipto Budoyo yang dimaksudkan adalah musik sebagai partner dalam sajian pertunjukan kesenian Gatholoco Cipto Budoyo. Peran musik dalam sajian pertunjukan kesenian Gatholoco Cipto Budoyo sangat penting yakni berfungsi sebagai penebal suasana dan juga berperan dalam hal menarik atau mengundang perhatian penonton.

Instrumen pada sajian musikal pertunjukan kesenian Gatholoco Cipto Budoyo yang memiliki peran sangat penting dalam hal tersebut adalah instrumen kendang. Instrumen kendang berfungsi sebagai pemimpin dalam pertunjukan Gatholoco Cipto Budoyo baik sajian musikal maupun tarinya. Pembicaraan mengenai perkembangan musikal kesenian Gatholoco kelompok seni Cipto Budoyo difokuskan pada pembahasan musikalitasnya yaitu alur sajian pertunjukan dan peranan instrumen kendang dalam sajian musikal pertunjukan kesenian Gatholoco Cipto Budoyo.

\section{Musik Kesenian Gatholoco Cipto Budoyo Periode I (1963-1980)}

Tahun 1960-an, jumlah seniman Gatholoco di daerah Kandangan masih sangat terbatas. Masa ini, satu-satunya kelompok kesenian Gatholoco di Kabupaten Temanggung berada di Desa Mbranti Kecamatan Kandangan. Kelompok kesenian ini beranggotakan sepuluh orang, empat orang diantaranya sebagai pemain musik dan enam orang lainnya sebagai penari. Dilihat dari latar belakang profesinya, pekerjaan mereka sehari- 
hari adalah petani dan pekebun. Proses penggarapan kesenian Gatholoco Desa Mbranti dilakukan secara komunal atau kolektif. Kondisi tersebut berpengaruh pada hasil sajian musikal kesenian Gatholoco Desa Mbranti yang memiliki bentuk sederhana dengan menggunakan pola-pola jalinan yang bersifat monoton (Muh. Hadi, wawancara 22 Desember 2017).

Tahun 1963, salah satu seniman Gatholoco dari Desa Mbranti yakni Badrun berpindah tempat ke Desa Kembangsari karena suatu hal. Hal tersebut, membuat Badrun memiliki inisiatif untuk memperkenalkan dan mengembangkan serta membentuk kelompok kesenian Gatholoco pada masyarakat Desa Kembangsari. Tahun 1964, Badrun dan para pelaku seni Gatholoco di desa Kembangsari, kemudian memberi nama kelompok kesenian Gatholoco ini dengan nama "Cipto Budoyo". Kesenian Gatholoco Cipto Budoyo memiliki fungsi sebagai sarana hiburan oleh masyarakat Desa Kembangsari.

Pertunjukan kesenian Gatholoco Cipto Budoyo terdapat dua unsur sajian pertunjukan, yakni pertunjukan musik dan tari. Musik dalam hal ini digunakan sebagai musik tari pada pertunjukan tari Gatholoco. Musik dalam kesenian Gatholoco Cipto Budoyo terdapat vokal lagu dan senggakan (vokal yang dilakukan oleh beberapa orang secara bersahutan) disela-sela pertunjukan musik. Senggakan yang dilakukan biasanya berisi syair bebas seperti ho'a, ho'é, ho'ya, lo, e', $o^{\prime}, y a^{\prime}$ dan lain sebagainya. Fungsi senggakan, sebagai pendukung suasana dalam sajian pertunjukan kesenian Gatholoco Cipto Budoyo agar lebih meriah dan menarik.

Tahun 1965, belum lama kesenian Gatholoco Cipto Budoyo muncul namun sudah mengalami kevakuman. Kondisi politik di Indonesia yang tidak stabil, terjadinya pemberontakan Partai Komunis Indonesia (PKI) dengan pemerintah, menyebabkan berbagai kegiatan kesenian di daerah Temanggung mengalami kevakuman, termasuk kesenian Gatholoco Cipto Budoyo. Seniman yang terlibat dalam Lembaga
Kebudayaan Rakyat (LEKRA), tidak berani melakukan kegiatan berkesenian karena organisasi tersebut dianggap terlarang oleh PKI. Peristiwa tersebut menyebabkan trauma yang mendalam bagi masyarakat khususnya para pelaku seni Gatholoco Cipto Budoyo. Terdapat beberapa seniman kesenian Gatholoco Cipto Budoyo mengasingkan diri untuk mencari keselamatan bagi dirinya maupun keluarga (Muh. Hadi, wawancara 22 Desember 2017).

Beberapa tahun setelah terjadi insiden tersebut, keadaan sudah mulai membaik, seiring dengan kondisi politik di Indonesia yang telah mereda. Tatanan kehidupan masyarakat Desa Kembangsari lambat laun telah kembali normal dan minat masyarakat terhadap kesenian muncul kembali. Tahun 1970-an, para pelaku kesenian Gatholoco Cipto Budoyo mulai melakukan kegiatan latihan kembali yang diprakarsai oleh Badrun. Sejak itulah awal mula terbentuknya sajian garap dalam kesenian Gatholoco Cipto Budoyo, baik dari segi musikalitas maupun dari segi tariannya.

\section{Musik Kesenian Gatholoco Cipto Budoyo Periode II (1981-2000)}

Perkembangan musikal kesenian Gatholoco pada periode ke dua berlangsung dalam kurun waktu 20 tahun, dimulai dari tahun 1981 hingga tahun 2000. Berdasarkan unsur yang menyertainya, musikalitas kesenian Gatholoco Cipto Budoyo masih terdapat kesamaan dengan pola sebelumnya, hanya saja terdapat beberapa pengembangan di dalamnya. Pengembangan tersebut ditunjukkan dengan penambahan pola-pola tabuhan masing-masing instrumen, penambahan jumlah instrumen, penambahan vokabuler lagu, dan dan vokal senggakan.

Terdapat perbedaan antara alur sajian periode ini dengan periode sebelumnya, yaitu terletak pada gerak tari Gatholoco yang disajikan. Periode ini, setiap vokabuler lagu yang disajikan mewakili satu gerak tarian yang membentuk huruf. Sajian awal hingga akhir, gerak tarian Gatholoco pada periode ini membentuk paduan huruf T-E-M-A-N-G-G-U- 
N-G. Lagu tersebut disajikan dua kali rambahan dalam penyajiannya.

\section{Musik Kesenian Gatholoco Cipto Budoyo Periode III (2001-2018)}

Berdasarkan unsur yang menyertainya, perkembangan musikal kesenian Gatholoco Cipto Budoyo masih terdapat kesamaan dan mengacu pada sajian musikal sebelumnya. Perkembangan yang mencolok ditunjukkan dengan adanya penambahan pola imbalan, penambahan instrumen, vokabuler materi lagu, dan senggakan yang digunakan dalam pertunjukan kesenian Gatholoco Cipto Budoyo. Penambahan vokabuler materi lagu dan vokal senggakan selain bertujuan untuk mendukung suasana dan pemanis dalam sajian pertunjukan kesenian Gatholoco Cipto Budoyo, namun dalam cakepan teks lagu yang disajikan juga mengandung pesan bagi para penonton. Berikut adalah tabel perkembangan garap dari periode 1 sampai dengan periode III kesenian Gatholoco Cipto Budoyo.

\begin{tabular}{|c|c|c|c|c|}
\hline \multirow{2}{*}{ No } & \multirow{2}{*}{ Unsur Garap } & \multicolumn{3}{|c|}{ Masa Perkembangan Garap } \\
\hline & & Periode I (1963-1980) & Periode II (1981-2000) & Periode III (2001-2018) \\
\hline 1 & Materi Garap & $\begin{array}{l}\text { - Lagu Kembang Peté } \\
\text { - Lagu Atur Sugeng } \\
\text { - Lagu Kembang Tela } \\
\text { - Lagu Gendhéng Kaca } \\
\text { - Lagu Kemelip } \\
\text { - Lagu Hak'é } \\
\text { - Lagu Macul } \\
\text { - Lagu Sinau } \\
\text { - Lagu Beras Jawo } \\
\text { - Lagu Kembang Resah } \\
\text { - Vokal Senggakanan ho'a, } \\
\text { ho'e, ho'ya, lo, e', o,', } \\
\text { ya'. }\end{array}$ & $\begin{array}{l}\text { - Penambahan vokabuler } \\
\text { lagu NKKBS dan Orde } \\
\text { Baru } \\
\text { - Penambahan vokal } \\
\text { senggakan "Sukseskan } \\
\text { Pembangunan" }\end{array}$ & $\begin{array}{l}\text { - Terdapat penambahan } \\
\text { bagian selingan di } \\
\text { tengah alur sajian } \\
\text { - Penambahan vokabuler } \\
\text { lagu Cowék Gopél, Samya } \\
\text { Ngudid, dan vokal } \\
\text { pembuka serta vokal } \\
\text { senggakan }\end{array}$ \\
\hline 2 & Penggarap & - Badrun & - Wartono & $\begin{array}{l}\text { - Muh. Hadi } \\
\text { - Darwanto } \\
\text { - Nanang Sulistyono }\end{array}$ \\
\hline 3 & Sarana Garap & $\begin{array}{l}\text { - Kendang (1 buah) } \\
\text { - Trebang (2 buah) } \\
\text { - Kempling (1 buah) }\end{array}$ & $\begin{array}{l}\text { - Kendang ( } 1 \text { buah) } \\
\text { - Trebang ( } 3 \text { buah) } \\
\text { - Kempling ( } 2 \text { buah) } \\
\text { - Jidor (1 buah) }\end{array}$ & $\begin{array}{l}\text { - Kendang ( } 1 \text { buah }) \\
\text { - Trebang ( } 3 \text { buah }) \\
\text { - Kempling ( } 2 \text { buah }) \\
\text { - Jidor }(1 \text { buah }) \\
\text { - Tamborin }(1 \text { buah }) \\
\text { - Angklung ( } 3 \text { buah })\end{array}$ \\
\hline 4 & $\begin{array}{l}\text { Prabot atau } \\
\text { Piranti Garap }\end{array}$ & $\begin{array}{l}\text { - Terdapat pola } \\
\text { sekaran kendang } \\
\text { sebanyak enam } \\
\text { sekaran dan satu } \\
\text { singgetan } \\
\text { - Pola imbalan pada } \\
\text { instrumen trebang } \\
\text { satu dan dua, } \\
\text { dengan satu } \\
\text { kempling }\end{array}$ & \begin{tabular}{|l|} 
- Terdapat pola sekaran \\
kendang sebanyak \\
delapan sekaran dan \\
dua singgetan \\
- Pola imbalan pada \\
instrumen trebang satu, \\
dua, dan tiga dengan \\
kempling satu dan dua, \\
serta satu jidor \\
\end{tabular} & \begin{tabular}{|l} 
- Terdapat pola sekaran \\
kendang sebanyak \\
enam sekaran dan dua \\
singgetan serta tiga pola \\
trék-trekan \\
- Pola imbalan pada \\
instrumen trebang satu, \\
dua, dan tiga dengan \\
kempling satu dan dua, \\
serta satu jidor. \\
- Pola imbalan pada \\
instrumen angklung \\
satu, dua dan tiga serta \\
tamborin \\
\end{tabular} \\
\hline 5 & Penentu Garap & $\begin{array}{l}\text { - Sarana hiburan } \\
\text { masyarakat }\end{array}$ & $\begin{array}{l}\text { - Sarana hiburan } \\
\text { masyarakat } \\
\text { - Keperluan kegiatan } \\
\text { pemerintahan }\end{array}$ & $\begin{array}{l}\text { - Sarana hiburan } \\
\text { masyarakat } \\
\text { - Keperluan festival } \\
\text { - Keperluan perlombaan } \\
\text { - Keperluan kegiatan } \\
\text { pemerintah } \\
\text { - Penyambutan tamu } \\
\text { kehormatan }\end{array}$ \\
\hline 6 & $\begin{array}{l}\text { Pertimbangan } \\
\text { Garap }\end{array}$ & $\begin{array}{l}\text { - Memenuhi kepuasan } \\
\text { batin pelaku seni itu } \\
\text { sendiri dan } \\
\text { masyarakat }\end{array}$ & $\begin{array}{l}\text { - Memenuhi kebutuhan } \\
\text { keperluan pemerintah } \\
\text { dan masyarakat }\end{array}$ & \begin{tabular}{|l|} 
- Memenuhi tuntutan \\
dan kriteria penilaian \\
dalam festival dan \\
perlombaaan
\end{tabular} \\
\hline
\end{tabular}

\section{Faktor Pendukung Perkembangan Musik Kesenian Gatholoco}

Proses perjalanan hidup kesenian Gatholoco Cipto Budoyo Desa Kembangsari yang berlangsung puluhan tahun berhasil mendapat simpati dari masyarakat. Usaha awal seniman Gatholoco Cipto Budoyo membuahkan hasil hingga kesenian ini meraih penghargaan di tingkat regional maupun nasional. Hal tersebut secara tidak langsung menyebabkan kesenian Gatholoco Cipto Budoyo semakin dikenal oleh masyarakat. Hal ini dimaksudkan untuk mempertahankan keberadaan kesenian Gatholoco Cipto Budoyo di tengah-tengah masyarakat. Upaya untuk berkembang dan mempertahankan keberadaannya tidak terlepas dari berbagai faktor pendukung.

Faktor-faktor pendukung terjadinya perkembangan musikal kesenian Gatholoco Cipto Budoyo didasarkan pada hubungan antara kesenian Gatholoco Cipto Budoyo dengan masyarakat. Hal ini sesuai dengan pernyataan Sedyawati sebagai berikut.

"Melihat bahwa bermacam peranan bisa dipunyai kesenian dalam kehidupan, dan peranan itu ditentukan oleh keadaan masyarakatnya, maka besarlah arti kondisi masyarakat ini bagi pengembangan kesenian. Apalagi bila kita membicarakan seni pertunjukan, karena seni pertunjukan itu pada pertamanya menyangkut suatu kerja kelompok dan keduanya itu membutuhkan hadirnya dua pihak yaitu penyaji dan penerima" (Sedyawati, 1981:61).

Sesuai pernyataan tersebut, kondisi masyarakat dapat menentukan arah perkembangan sebuah kesenian, khususnya seni pertunjukan. Hal ini dapat terjadi karena adanya hubungan timbal balik antara masyarakat penyaji dan masyarakat penerima. Masyarakat penyaji yang dimaksud adalah para pelaku kesenian Gatholoco Cipto Budoyo itu sendiri, sedangkan masyarakat penerima yaitu masyarakat penonton atau penikmat kesenian. 
Pendukung perkembangan musikal kesenian Gatholoco Cipto Budoyo tidak hanya berasal dari pelaku seni yang sudah tua, namun para pelaku seni muda juga ikut andil dalam hal tersebut. Guna menjaga kualitas dalam pertunjukannya, pelaku kesenian Gatholoco Cipto Budoyo senantiasa melakukan pengembangan, baik dari segi musikal maupun tarian. Hal ini sesuai dengan pernyataan Soedjatmoko, sebagai berikut.

"Setiap kebudayaan, setiap masyarakat yang vital, untuk menjaga vitalitasnya itu, harus memupuk dua unsur kehidupannya, yaitu kontinisiusnya serta kesanggupannya untuk berubah, atau tradisinya dan pembaharuannya. Dan setiap kebudayaan dan masyarakat yang vital itu, mau tak mau menyadari bahwa aktivitas intelektual dan budaya ini, ialah tempat bertahtanya "imajinasi kreatif" bangsa" (Soedjatmoko, 1983:60).

Berdasarkan konsep di atas, faktor yang mendorong terjadinya perkembangan musikal kesenian Gatholoco Cipto Budoyo terbagi menjadi dua faktor, yakni faktor internal dan faktor eksternal. Mengenai penjelasan tentang faktor internal dan eksternal dalam perkembangan musikal kesenian Gatholoco Cipto Budoyo dipaparkan sebagai berikut.

\section{Faktor Internal}

Faktor internal yang dimaksud disini adalah penyebab terjadinya perkembangan musikal kesenian Gatholoco Cipto Budoyo yang berasal dari dalam, yaitu pelaku kesenian itu sendiri. Tumbuhnya kesadaran dalam budaya, memicu para pelaku kesenian Gatholoco Cipto Budoyo untuk melakukan pengembangan musikalitas pada kesenian Gatholoco. Terdapat beberapa faktor internal yang mendorong perkembangan musikal kesenian Gatholoco Cipto Budoyo, sebagai berikut.

\section{a. Motivasi Anggota}

Manusia adalah makhluk yang berbudaya, oleh sebab itu manusia selalu ada keinginan untuk meningkatkan diri, berubah dan berkembang dari apa yang telah dimiliki, mendambakan kemajuan untuk kesejahteraan yang lebih baik. Hal ini menunjukan bahwa perjalanan hidup manusia tidak statis, melainkan senantiasa tampil dengan proses dinamika budaya lingkungannya. Pernyataan tersebut dipertegas oleh pendapat Koentjaraningrat, sebagai berikut.

“Di dalam tiap-tiap kelompok manusia berdjuang dengan tjaranja sendirisendiri, membentuk kebudayaannja sendiri-sendiri. Tetapi keadaan kelompok masing-masing tidak tetap dengan ta' berobah : banjak unsur didalam masjarakat manusia itu, jang menjebabkan suatu perobahan ta' ada hentinja. Misalnja, bertambah atau berkurangnja anggauta masjarakat, berobahnja keadaan bumi, berobahnja pentjaharian hidup, dsb. Selalu menjebabkan bahwa kelompok manusia itu berobah" (Koentjaraningrat, 1954 : 13).

Pernyataan yang disampaikan oleh Koentjaraningrat juga berdampak pada perkembangan musikal kesenian Gatholoco Cipto Budoyo. Salah satunya adalah para pelaku seni Gatholoco Cipto Budoyo menyesuaikan perkembangan yang ada di zaman sekarang. Muncul keinginan dari para pelaku seni Gatholoco Cipto Budoyo untuk selalu meningkatkan kemampuan dalam dirinya. Hal tersebut wajar, sebab itu bagian dari sifat alamiah manusia yang tidak dapat dihindarkan dan setiap manusia memiliki bakat untuk selalu mengembangkan diri demi mencapai kesejahteraan hidup seperti yang diinginkan.

Kasus dalam bidang berkesenian khususnya kesenian Gatholoco Cipto Budoyo, wujud sifat dinamis manusia yang selalu ingin mencapai kemajuan, tercermin pada tindakan yang dilakukan untuk mencari kemungkinan hal-hal baru. Tujuannya agar kesenian Gatholoco Cipto Budoyo tetap hidup dan eksis mengikuti perkembangan zaman. Upaya pengembangan oleh para pelaku seni Gatholoco Cipto Budoyo tidak terlepas dari segi sosial budaya yang merangsang terjadinya perkembangan tersebut. Motivasi dari para 
pelaku seni Gatholoco Cipto Budoyo merupakan salah satu pendorong terjadinya perkembangan. Hal tersebut ditunjukkan dengan adanya keinginan dan semangat dari para pelaku seni Gatholoco Cipto Budoyo untuk mempertahankan dan memajukan kesenian Gatholoco Cipto Budoyo.

\section{b. Kreativitas Seniman}

Faktor internal lain yang juga sangat penting untuk mendukung proses perkembangan musikal kesenian Gatholoco Cipto Budoyo, yaitu kreativitas seniman. Pembaharuan dan perkembangan yang dilakukan merupakan hasil dari kemampuan dan kreativitas seniman. Definisi kreativitas dijelaskan oleh Primadi, sebagai berikut.

"Kreativitas adalah salah satu kemampuan manusia yang dapat membantu kemampuan-kemampuannya yang lain, hingga sebagai keseluruhan dapat mengintegrasikan stimuli-luar (apa yang melanda dari luar sekarang) dengan stimuli-dalam (apa yang telah dimiliki sebelumnya, memori hingga tercipta suatu kebulatan yang baru)" (Primadi, 1978:29).

Seorang seniman ketika minim daya kreativitasnya atau tidak memiliki sifat kreatif, maka kesenian tersebut akan mati atau hilang karena tertinggal oleh kemajuan zaman. Sifat kreatif itu sendiri membutuhkan proses atau waktu yang cukup panjang. Kreativitas seorang seniman terbentuk karena kebiasaan seseorang dalam menekuni suatu hal. Hal ini terlihat pada para pelaku seni Gatholoco Cipto Budoyo yang menekuni atau berkecimpung dalam kesenian Gatholoco. Seorang seniman atau pelaku seni, apabila sudah lama menekuni dalam dunia seni khususnya kesenian Gatholoco Cipto Budoyo, maka dengan mudah seniman tersebut mengeksplorasi atau mengekspresikan idenya ke dalam sebuah bentuk sajian garap pertunjukan. Terdapat dua unsur yang menimbulkan sifat kreatif di dalam diri seorang seniman, yakni muncul dari dalam (stimuli dalam) dan muncul karena rangsangan dari luar (stimuli luar). Kreativitas seniman dalam proses perkembangan musikal kesenian Gatholoco Cipto budoyo, dapat dikategorisasikan menjadi empat peranan. Masing-masing peranan tersebut dijelaskan sebagai berikut.

1) Penata Musik

Bentuk kreativitas seniman Gatholoco kelompok seni Cipto Budoyo sebelum adanya penata musik, merupakan hasil ide atau gagasan bersama antara pemain musik dan penari. Gagasan tersebut muncul dari kedua belah pihak, kemudian ditampung menjadi sebuah konsep, dan divisualisasikan berdasarkan peran masing-masing. Pengembangan musikalitas kesenian Gatholoco Cipto Budoyo sebelum ada campur tangan dari penata musik, berasal dari hasil mufakat para pelaku seni yang terlibat dalam kesenian Gatholoco Cipto Budoyo.

Tahun 1980-an merupakan awal munculnya gagasan penata musik pada musikalitas kesenian Gatholoco Cipto Budoyo. Wujud kreativitas yang terdapat pada musikalitas kesenian Gatholoco Cipto Budoyo sebelumnya, menarik perhatian penata musik untuk ikut andil dan berperan dalam pengembangan musikalitas kesenian Gatholoco Cipto Budoyo. Hal tersebut digunakan sebagai pancatan dalam proses pengembangan musikal kesenian Gatholoco Cipto Budoyo menjadi semakin baik. Penata musik yang berlatar belakang seniman, juga mempengaruhi vokabuler dan repertoar musikal kesenian Gatholoco Cipto Budoyo. Hal ini disebabkan karena penata musik merupakan salah satu penentu berhasil atau tidaknya garap musik disajikan. Sesuai dengan pernyataan yang dikemukakan oleh Supangah sebagai berikut.

Merekalah yang paling menentukan warna, rasa, dan kualitas garap, karena merekalah yang menentukan hampir segalanya: dari memilih (versi balungan) dan/atau menafsir gending, menabuh ricikan dengan memilih tehnik, cengkok, pola tabuhan dan wiledan vokal dalam menggarap gending, juga termasuk bagaimana mereka mengemas 
dan menyajikan gending di "hadapan" penikmat atau penghayatnya. Kualitas hasil garapan dengan demikian tergantung pada kapasitas, kreativitas, dan kualitas si seniman penggarap, si pengrawit (Supanggah, 2007:149).

Masuknya penata musik dalam kelompok kesenian Gatholoco Cipto Budoyo ini menjadi penting keberadaannya. Penata musik dituntut untuk lebih peka dalam melihat dan menentukan perkembangan musikal kesenian Gatholoco Cipto Budoyo. Adanya peran penata musik dalam kesenian Gatholoco Cipto Budoyo ini, maka di setiap pementasan atau pertunjukan akan melalui proses pertimbangan garap. Wujud peran penata musik dalam kesenian Gatholoco Cipto Budoyo, yakni pada tahun 1980-an terdapat penambahan instrumen musik kesenian Gatholoco Cipto Budoyo, penambahan instrumen, vokabuler lagu dan senggakan. Hal selain itu yakni, adanya perubahan pola gerak tarian dalam pertunjukan kesenian Gatholoco Cipto Budoyo yang membentuk formasi huruf T-E-M-A-N-G-G-U-N-G. Perkembangan tersebut dilakukan untuk keperluan pentas kesenian di Taman Mini Indonesia Indah (TMII) Jakarta.

\section{2) Pemain musik}

Pemain musik atau dalam karawitan Jawa disebut sebagai pengrawit, juga ikut berpengaruh dalam proses perkembangan musikal kesenian Gatholoco Cipto Budoyo, dan tergolong salah satu unsur dari kreativitas seniman. Pemain musik sebagai pendukung internal baik secara pribadi maupun berkelompok, para pemain musik kesenian Gatholoco Cipto Budoyo sangat berperan atas proses perkembangan musikal kesenian Gatholoco Cipto Budoyo. Usaha untuk tetap eksis dalam masyarakat, secara tidak langsung telah terjadi persaingan antara pemain musik kesenian Gatholoco Cipto Budoyo dengan pemain musik kesenian lain yang ada di Kabupaten Temanggung. Setiap seniman khususnya para pemain musik berlombalomba untuk menonjolkan kemampuan demi popularitas masing-masing.
Arah perkembangan musikal kesenian Gatholoco Cipto Budoyo, selain berasal dari kemampuan pemain musik, tetapi juga berdasarkan pada latar belakang pemain musik tersebut dalam memperoleh kemampuannya. Pemain musik kelompok kesenian Gatholoco Cipto Budoyo sebagian besar mendapat kemampuan menabuh diperoleh secara otodidak. Adanya pemain musik dengan latar belakang akademisi seni, juga mendorong terjadinya perkembangan musikal pada kelompok kesenian Gatholoco Cipto Budoyo Desa Kembangsari.

Peran kreativitas seniman dari segi pemain musik kesenian Gatholcoco Cipto Budoyo, terlihat pada terbentuknya pola-pola jalinan tabuhan antara instrumen trebang dan kempling pada bagian senggakan. Pola tabuhan instrumen trebang dan kempling pada bagian senggakan lagu Gatholoco yang sekarang berbeda dengan tabuhan sebelumnya. Hal tersebut muncul karena terdapat sifat kreatif dalam diri pemain musik kesenian Gatholoco Cipto Budoyo. Peran pemain musik, khususnya pengendang juga dituntut memiliki kreativitas yang tinggi.

Terlihat pada bagian selingan dalam pertunjukan kesenian Gatholoco Cipto Budoyo, pengendang harus tanggap dengan salah satu penari Gatholoco yang melakukan gerak tarian secara spontan. Bagian selingan dalam pertunjukan kesenian Gatholoco Cipto Budoyo pada dasarnya bersifat bebas, maka dari itu seluruh pemain musik harus memiliki sifat kreatif untuk mengantisipasi hal-hal yang bersifat spontan.

\section{3) Penggerong}

Perkembangan yang terjadi pada kelompok kesenian Gatholoco Cipto Budoyo juga didukung dengan keberadaan penggerong atau vokal vokal putra dalam sajian musikalitas pertunjukan Gatholoco. Pertunjukan kesenian Gatholoco Cipto Budoyo tidak menggunakan pesindhén (vokal putri), karena memang dari awal terbentuknya kesenian ini semua pemainnya adalah laki-laki, baik itu dari segi pemain musik maupun penari. Salah satu penggérong yang sangat perperan 
dalam proses perkembangan musikal kesenian Gatholoco Cipto Budoyo adalah Sugito. Sugito merupakan salah seorang penggerong kesenian Gatholoco Cipto Budoyo yang masih bertahan sampai sekarang. Ia telah menciptakan senggakan-senggakan baru dan lirik vokal baru dalam vokabuler lagu kesenian Gatholoco Cipto Budoyo.

Peran kretivitas penggérong dalam pertunjukan kesenian Gatholoco Cipto Budoyo, dapat dilihat pada terciptanya lagulagu dalam kesenian Gatholoco Cipto Budoyo seperti Tembang Macul, Tembang Sinau, Kembang Peté, Kembang Téla, dan lain sebagainya. Lagu tersebut diciptakan oleh salah satu penggerong kesenian Gatholoco Cipto Budoyo pada masa awal keberadaannya. Syair atau lirik lagu tersebut menggambarkan kegiatan masyarakat Desa Kembangsari sehari-hari dan berisi ajaran kepada anak-anak untuk selalu belajar. Terdapat contoh kasus lain, yakni dari segi senggakan dalam pertunjukan kesenian Gatholoco Cipto Budoyo. Senggakan yang dilakukan antara pemain satu dengan yang lain berbeda. Perbedaan terletak pada cengkok atau pelaguan yang dimainkan. Permainan céngkok oleh penggerong terlihat paling menonjol yakni pada saat melakukan vokal pembuka (buka celuk dalam istilah karawitan Jawa).

\section{4) Penari}

Kesenian Gatholoco Cipto Budoyo dalam pertunjukannya, melibatkan sejumlah. Setiap penari memiliki penafsiran terhadap sajian musik yang dilakukan oleh para pemain musik kesenian Gatholoco Cipto Budoyo. Masing-masing penari memiliki kemampuan penafsiran, sehingga menambah banyaknya vokabuler pengembangan gerak tari. Hal tersebut secara tidak langsung berpengaruh pada sajian musikal dalam tarian kesenian Gatholoco Cipto Budoyo. Komunikasi antara penari dan pemain musik menjadi sangat penting dalam sebuah pertunjukan rakyat seperti kesenian Gatholoco Cipto Budoyo. Oleh sebab itu, penari memiliki peran dalam mendorong terjadinya perkembangan musikal kesenian Gatholoco Cipto Budoyo.
Contoh kasus dalam hal ini adalah, adanya gerakan baru yang dilakukan oleh penari Gatholoco saat latihan maupun pementasan dan mengharuskan para pemain musik tanggap untuk melakukan sajian musikal menyesuaikan gerak tari tersebut. Pemain yang dituntut paling tanggap dalam hal ini adalah pemain instrumen kendang. Sebab, pemain instrumen kendang memiliki peran yang sangat penting dalam pertunjukan kesenian Gatholoco Cipto Budoyo. Pemain instrumen kendang dalam pertunjukan kesenian Gatholoco memiliki peran sebagai pemimpin sajian musikal, selain itu juga memimpin jalannya sajian pertunjukan tari Gatholoco dan dijadikan panutan oleh semua penari.

Guna mencapai tujuan bersama, dalam pertunjukan kesenian Gatholoco Cipto Budoyo tidak dapat didominasi oleh individu, baik itu penari maupun pemain musik. Setiap penari harus mengikuti peraturan yang telah disepakati bersama (penari dan pemain musik), sehingga terjalin keharmonisan dalam pertunjukan kesenian Gatholoco Cipto Budoyo. Semua pemain harus mematuhi kesepakatan yang telah dicapai, meskipun terdapat susunan adegan dan peran secara universal namun masing-masing penari juga harus memiliki cara untuk melakukan tanggung jawabnya sesuai dengan kemampuan yang dimiliki.

\section{Faktor Eksternal}

Perkembangan yang terjadi dalam sajian musikal kesenian Gatholoco Cipto Budoyo juga dipengaruhi oleh faktor dari luar (eksternal). Faktor eksternal juga dapat menentukan arah perkembangan musikal kesenian Gatholoco Cipto Budoyo. Terdapat beberapa faktor eksternal yang mendorong perkembangan musikal kesenian Gatholoco Cipto Budoyo seperti, masyarakat penggemar, perkembangan teknologi, pemerintah atau dinas terkait, dan persaingan kelompok. Penjelasan mengenai faktor-faktor tersebut sebagai berikut.

a. Masyarakat Penggemar

Berhasil atau tidaknya perkembangan yang terjadi pada sebuah kesenian, dapat 
bergantung pada respon masyarakat. Masyarakat apabila dapat menerima pembaharuan sebuah kesenian, maka kesenian tersebut dapat bertahan hidup dan tetap eksis. Sebaliknya, apabila masyarakat penggemar tidak dapat menerima pembaharuan dari kesenian tersebut, maka usaha pembaharuan yang dilakukan oleh pelaku seni tidak akan membuahkan hasil seperti yang diharapkan.

Masyarakat penggemar kesenian Gatholoco Cipto Budoyo terdiri dari berbagai kalangan, yakni dari kalangan anak-anak, kalangan muda, sampai kalangan tua. Setiap pementasan kesenian Gatholoco Cipto Budoyo saat ini, khususnya di wilayah Kandangan dan umumnya wilayah Temanggung lebih didominasi penggemar dari kalangan muda dan anak-anak. Usia penggemar mulai dari 7 tahun hingga 60 tahun.

Apresiasi yang dilakukan oleh para penggemar khususnya dari kalangan muda, hampir selalu ada dalam setiap pementasan. Mereka datang tidak hanya satu atau dua orang, melainkan secara berkelompok. Setiap kelompok masyarakat penggemar terdiri dari kurang lebih 10 orang. Terdapat juga masyarakat penggemar kesenian lain yang turut mengapresiasi kesenian Gatholoco Cipto Budoyo ketika pentas, seperti masyarakat penggemar kesenian Kuda Lumping, Topéng Ireng, Topéng Lénggér, dan lain sebagainya.

Adanya masyarakat penggemar yang ikut bergabung dalam pertunjukan kesenian Gatholoco saat berlangsung merupakan salah satu wujud peran masyarakat dalam upaya pengembangan kesenian Gatholoco Cipto Budoyo. Keikutsertaan penonton dalam pertunjukan ini, biasanya terletak pada bagian selingan atau lelucon. Wujud keikutsertaan penonton dapat dilihat yakni pada saat penonton ikut menari dan bernyanyi, bahkan ada juga salah satu penggemar yang request lagu-lagu dangdut koplo saat ini. Secara tidak langsung, para pemain musik kesenian Gatholoco Cipto Budoyo harus menuruti permintaan tersebut. Hal tersebut juga dapat menjadi salah satu pemicu adanya pengembangan sajian musikal dalam pertunjukan kesenian Gatholoco Cipto Budoyo.

\section{b. Perkembangan Teknologi}

Perkembangan teknologi pada dasarnya merupakan kebutuhan sekunder bagi setiap manusia. Salah satu wujud dari adanya perkembangan teknologi yaitu ditunjukan dengan kecanggihan alat komunikasi. Jenis alat komunikasi di zaman sekarang sangat beragam, diantaranya audio, visual, dan audio-visual. Melalui alat komunikasi semua informasi dapat disampaikan dengan cepat dan efisien.

Masuknya teknologi komunikasi baik media massa, telepon, radio, televisi dan lainnya menyebabkan seluruh lapisan masyarakat khususnya Desa Kembangsari dapat dengan mudah berkomunikasi dengan dunia luar, serta dengan cepat menyerap berbagai informasi dari luar, baik itu informasi politik, sosial, budaya, ekonomi dan lain sebagainya. Salah satu wujud adanya perkembangan teknologi yakni saat kesenian Gatholoco Cipto Budoyo melakukan pementasan dalam acara festival atau perlombaan kemudian diliput dalam media cetak maupun audio visual.

Secara tidak langsung, hal tersebut dapat membuat masyarakat luas ikut mengapresiasi dan menyaksikan pertunjukan kesenian Gatholoco Cipto Budoyo. Terlebih sekarang Kabupaten Temanggung sudah memiliki stasiun televisi sendiri. Hal ini merupakan salah satu wujud adanya perkembangan dan kemajuan teknologi sekarang yang berdampak pada kesenian rakyat khususnya kesenian Gatholoco Cipto Budoyo. Oleh karena itu, perkembangan dan kemajuan teknologi menjadi salah satu faktor pendukung terjadinya perkembangan dan pelestarian terhadap kesenian Gatholoco Cipto Budoyo.

\section{c. Pemerintah atau Dinas Terkait}

Sejak tahun 1980-an kesenian Gatholoco Cipto Budoyo mendapat perhatian dari pemerintah dan dinas terkait. Pemerintah juga memberikan pengaruh yang besar terhadap perkembangan kesenian Gatholoco di Desa Kembangsari. Pada tahun 1982, pihak pemerintah dan dinas terkait mengirimkan pelatih untuk melatih para pelaku kesenian 
Gatholoco Cipto Budoyo untuk persiapan pentas di Taman Mini Indonesis Indah (TMII) Jakarta. Pemerintah juga memberikan bantuan dana untuk pembaruan alat musik dan kostum serta properti pementasan pada kesenian Gatholoco Cipto Budoyo.

Wujud dukungan dari pemerintah atau dinas terkait terhadap kesenian Gatholoco Cipto Budoyo, yakni kesenian Gatholoco Cipto Budoyo selalu diikutsertakan dalam acara yang diselenggarakan oleh pemerintah, seperti karnaval, festival atau parade kesenian, dan acara lainnya. Dukungan yang diberikan oleh pemerintah atau dinas terkait terhadap kesenian Gatholoco Cipto Budoyo, membuat para pelaku seni Gatholoco Cipto Budoyo semakin bersemangat untuk berkreativitas dan mengembangkan kesenian Gatholoco Cipto Budoyo.

\section{d. Persaingan Kelompok}

Potensi kesenian yang hidup dan berkembang di Kabupaten Temanggung merupakan sebagian kecil dari sekian banyaknya kekayaan budaya bangsa. Potensi tersebut secara langsung maupun tidak langsung, mendukung terjadinya perkembangan antara kesenian satu dengan kesenian yang lain. Hal ini dapat dilihat dari keterlibatan para pelaku kesenian lain yang ada di Desa Kembangsari khususnya, ikut andil dalam proses musikalitas kesenian Gatholoco Cipto Budoyo. Seniman dari berbagai kalangan seperti, pelaku kesenian Jaranan, Njanén, Topéng Ireng, Kuda Lumping, dan Kubro Siswo ikut andil mendukung serta terlibat dalam proses pengembangan musikalitas kesenian Gatholoco Cipto Budoyo. Hal tersebut merupakan salah satu faktor eksternal perkembangan musikal kesenian Gatholoco Cipto Budoyo dewasa ini.

Bagi kesenian Gatholoco Cipto Budoyo, adanya kelompok kesenian lain yang juga banyak bermunculan dan berkembang merupakan tantangan untuk bersaing. Persaingan ini lebih memicu kesenian Gatholoco Cipto Budoyo untuk senantiasa mengembangkan kreativitas dan selalu mencari alternatif baru guna meningkatkan kualitas dan tetap eksis dalam lingkungan masyarakat. Salah satu alternatif adalah dengan memasukkan unsur garap kesenian lain, dan penambahan instrumen pendukung pada sajian musikal kesenian Gatholoco Cipto Budoyo.

Perkembangan musikal kesenian Gatholoco Cipto Budoyo didorong oleh persaingan dengan jenis-jenis hiburan modern seperti musik, film, dan beberapa seni modern lain, yang selama ini dirasa telah menyudutkan kehidupan kesenian tradisi khususnya kesenian Gatholoco Cipto Budoyo. Tujuan adanya pengembangan pada sajian musikal kesenian Gatholoco adalah untuk mengantisipasi dan mengikuti perkembangan zaman dan guna mencapai kemampuan bersaing dengan kelompok kesenian tradisi maupun kelompok kesenian modern yang lain.

\section{Kesimpulan}

Berdasarkan uraian dan pembahasan yang telah dipaparkan pada bab-bab sebelumnya, maka dapat ditarik kesimpulan mengenai perkembangan musikal pada kesenian Gatholoco Cipto Budoyo Desa Kembangsari Kecamatan Kandangan Kabupaten Temanggung. Musikal kesenian Gatholoco Cipto Budoyo yang telah mengalami perkembangan seperti sekarang, terdapat benang merah dengan musikal kesenian Gatholoco Cipto Budoyo sebelumnya. Proses perkembangan musikal kesenian Gatholoco Cipto Budoyo sudah berlangsung selama puluhan tahun, tetapi pola-pola yang terdapat pada musikal kesenian Gatholoco Cipto Budoyo terdahulu masih digunakan. Garap musikal kesenian Gatholoco Cipto Budoyo mengalami perkembangan berdasarkan unsur-unsur yang menyertainya. Unsur-unsur garap tersebut diantaranya; materi garap, penggarap, sarana garap, perabot atau piranti garap, penentu garap, serta pertimbangan garap. Unsur-unsur tersebut secara kronologis mengalami perkembangan dari tahun 1963-1980 (periode pertama), tahun 1981-2000 (periode ke dua), dan tahun 2001-2018 (periode ke tiga).

Tahun 1963-1980 (periode pertama) merupakan masa awal keberadaan musikal 
kesenian Gatholoco Cipto Budoyo. Masa ini instrumen yang digunakan dalam musikal kesenian Gatholoco Cipto budoyo terdiri dari; 1 buah kendang, 2 buah trebang, dan 1 buah kempling serta vokal. Instrumen-instrumen tersebut memiliki peran dan fungsi masingmasing. Vokabuler lagu dalam musikal kesenian Gatholoco Cipto Budoyo berasal dari lagu-lagu kesenian Wulang Sunu yang merupakan cikal bakal lahirnya kesenian Gatholoco Cipto Budoyo. Lagu yang digunakan dalam kesenian Wulang Sunu dan Gatholoco Cipto Budoyo memiliki ciri dan kekhasan masing-masing. Fungsi kesenian Gatholoco Cipto Budoyo pada masa ini adalah sebagai sarana hiburan masyarakat Desa Kembangsari.

Tahun 1981-2000 (periode ke dua) merupakan masa awal perkembangan musikal kesenian Gatholoco Cipto Budoyo setelah mengalami kevakuman cukup panjang. Indikasi yang menunjukan perkembangan musikal kesenian Gatholoco Cipto Budoyo adalah adanya penambahan instrumen dan penggarapan ulang pola-pola tabuhan maupun tarian, serta penambahan vokabuler lagu dan vokal senggakan dalam lagu-lagu yang digunakan dalam kesenian Gatholoco Cipto Budoyo. Penambahan vokabuler lagu dan vokal senggakan dalam kesenian Gatholoco Cipto Budoyo tersebut digunakan untuk menambah dinamika dalam pertunjukan keseniain Gatholoco Cipto Budoyo agar suasana lebih ramai, meriah, dan menarik. Senggakan yang digunakan diantaranya; $h a^{\prime} e$, ho'ya, lo, e', o'. Senggakan dalam lagu Gatholoco pada periode kedua ini sudah mulai ditambah dengan slogan-slogan yang berisi tentang program pemerintah seperti; sukseskan pembangunan, sukseskan program $K B$, dan lain sebagainya.

Keberhasilan peran penggarap yang dilakukan pada tahun 1980-an, membuka peluang seniman atau pelaku seni yang lain untuk menggarap musik kesenian Gatholoco Cipto Budoyo di masa mendatang. Penambahan materi garap dan sarana garap pada kesenian Gatholoco Cipto Budoyo, menjadikan kelompok kesenian ini mengalami kemajuan dan tetap eksis dikalangan masyarakat. Upaya yang dilakukan membuahkan hasil, ditunjukkan dengan indikasi masuknya penggarap pada masa selanjutnya, maka menjadikan minat masyarakat dengan kesenian Gatholoco Cipto Budoyo semakin banyak.

Masa perkembangan selanjutnya yakni periode ke tiga (tahun 2001-2018), kesenian Gatholoco Cipto Budoyo dalam pertunjukannya dikemas menjadi lebih menarik, seperti munculnya kesenian Gatholoco putri dan kesenian Gatholoco oleng. Sajian pertunjukan Gatholoco putri maupun Gatholoco oleng, garap musikal yang disajikan tidak meninggalkan lagu dan pola-pola dasar musikal kesenian Gatholoco Cipto Budoyo terdahulu. Terdapat penambahan vokabuler lagu dan instrumen yang digunakan dalam musikalitas kesenian Gatholoco Cipto Budoyo. Penambahan vokabuler lagu ini terletak pada bagian awal pertunjukan kesenian Gatholoco Cipto Budoyo, yakni vokal pembukaan. Penambahan instrumen baru pada masa ini yaitu instrumen tamborin dan angklung.

Perkembangan musikal kesenian Gatholoco pada kelompok Cipto Budoyo yang terjadi, tidak terlepas dari faktor pendukung. Faktor-faktor pendukung tersebut meliputi faktor internal dan faktor eksternal. Faktor internal perkembangan musikal kesenian Gatholoco Cipto Budoyo meliputi; motivasi anggota, dan kreativitas seniman (penata musik, pemain musik, penggerong, dan penari). Faktor eksternal perkembangan musikal kesenian Gatholoco Cipto Budoyo diantaranya meliputi; masyarakat penggemar, perkembangan teknologi, pemerintah atau dinas terkait, dan persaingan kelompok.

\section{Kepustakaan}

Kartodirdjo, Sartono. 1992. Pendekatan Ilmu Sosial Dalam Metodologi Sejarah. Jakarta: PT. Gramedia Pustaka Utama.

Koentjaraningrat. 1984 . Pengantar Ilmu Antropologi. Jakarta: Aksara Baru. 
Maryono. 2015. Analisa Tari. Surakarta: ISI Press Solo

Perwita Putra, Nawan. 2012. "Perubahan Fungsi Gending: Studi Kasus Ketawang Puspawarna". Surakarta : ISI Surakarta. Skripsi

Sedyawati, Edy. 1981. Pertumbuhan Seni Pertunjukan. Jakarta: Sinar Harapan.

Soedarsono. 1872. Djawa dan Bali Dua Pusat Perkembangan Drama Tari Tradisional di Indonesia. Yogyakarta: Gajah Mada, University Press.

Soedjatmoko. 1983. Dimensi Manusia Dalam Pembangunan: Pilihan Karangan. Jakarta: LP3E5

Supanggah, Rahayu. 2007. Bothekan Karawitan II : Garap. Surakarta: ISI Press Surakarta.

Wibisono, Singgih. dkk. 1985. Ensiklopedi Tari Indonesia. Jakarta: Dep P\&K

\section{Daftar Narasumber}

1. Muh. Hadi (74 tahun) ketua kelompok kesenian Gatholoco Cipto Budoyo periode II. Alamat Dusun Tanjungan, Desa Kembangsari, Kecamatan Kandangan, Kabupaten Temanggung.

2. Sugito (64 tahun), pelaku kesenian Gatholoco Cipto Budoyo berperan sebagai vokal. Alamat Dusun Tanjungan, Desa Kembangsari, Kecamatan Kandangan, Kabupaten Temanggung.

3. Darwanto (38 tahun), ketua kelompok kesenian Gatholoco Desa Kembangsari periode III (sekarang). Alamat Dusun Tanjungan, Desa Kembangsari, Kecamatan Kandangan, Kabupaten Temanggung.

4. Tri Puji Waluyo (35 tahun), tokoh masyarakat Dusun Tanjungan, penanggung jawab kesenian Gatholoco Cipto Budoyo periode III (sekarang). Alamat Dusun Tanjungan, Desa Kembangsari, Kecamatan Kandangan, Kabupaten Temanggung. 